\title{
Assessment of ICT Skills Relevant for Effective Learning Possessed by Undergraduate Students at University of Nigeria
}

\author{
Basil C.E Oguguo ${ }^{1}$, Agnes O. Okeke ${ }^{1}$, Priscilla O. Dave-Ugwu ${ }^{1}$, Christopher A. Ocheni ${ }^{1}$, Clifford O. Ugorji ${ }^{2}$, Ijeoma \\ Hope N. Nwoji \& Iheanacho C. Ike ${ }^{2}$ \\ ${ }^{1}$ Department of Science Education, University of Nigeria, Nsukka, Nigeria \\ ${ }^{2}$ Department of Physical Science Education, Imo State University, Owerri, Imo State, Nigeria \\ ${ }^{2}$ Department of Mathematics, Alvan Ikoku Federal College of Education, Owerri, Imo State, Nigeria \\ Correspondence: Agnes O. Okeke, Department of Science Education, University of Nigeria, Nsukka, Nigeria. E-mail: \\ obianuju.okeke@unn.edu.ng.
}

Received: April 27, 2020

Accepted: June 17, 2020

Online Published: June 18, 2020

doi:10.5430/ijhe.v9n4p206

URL: https://doi.org/10.5430/ijhe.v9n4p206

\begin{abstract}
This study examined the information and communication technology (ICT) skills relevant for effective learning possessed by undergraduate students. The study made use of descriptive survey research design. The study participants were 320 undergraduate students of university of Nigeria. The instrument used for data collection was "Relevant ICT Skills for Effective Learning among Undergraduate Students Questionnaire" (RISELUSQ). The reliability of the instrument was determined using Cronbach-Alpha method and a reliability coefficient of 0.84 was obtained. Four research questions and two hypotheses guided the study. The data collected were subjected to analysis, the mean and standard deviation were used to answer the research questions while the hypotheses were tested using t-test and ANOVA at 0.05 level of significance. The findings revealed that undergraduate students possessed the relevant ICT skills that will enhance their learning and that the ICT skills of the male students were not different from that of the female. The findings also showed that the ICT skills of undergraduate students differ based on their educational level, particularly, between the 100 level and 500 levels. Equally, the finding reveals that the students face some ICT challenges like non-functional/limited projectors in classrooms, limited e-learning facilities among others. Based on the findings, it was recommended that students be encouraged to continue to improve on their ICT skills as it will enable them strive well academically and that school authorities should ensure adequate and proper infrastructures/ICT facilities be put in place within the university environment.
\end{abstract}

Keywords: Information \& Communication Technology, assessment, ICT skills for learning, higher education

\section{Introduction}

The broad purpose of this study is to assess information and communication technology skills relevant for effective learning possessed by undergraduate students in University of Nigeria, Nsukka. In our contemporary time, the place of technology cannot be overemphasized, before now people used to think that just like other things come and go, technology has come and would definitely go. However, information and communication Technology (ICT) has proved otherwise as it keeps getting better day by day, improving and expanding in various aspects. This improvement and expansion has continued to improve mankind, facilitate growth and development among others. Of course, the education sector is never left out ofthe increase brought about by ICT. According to United Nation Educational, Scientific and Cultural Organization (UNESCO; 2002),ICT is like the foundation for every other thing in our contemporary world; hence, a deeper knowledge of this advancement in knowledge is essential for proper education.ICT as defined by UNESCO (2006) means those forms of technology that are used for transmitting, saving, creating or sharing information. This definition implies that ICT include various kind of technology like the telephones, televisions, video, computer hardware and software, DVD among others.Beebe (2004) as cited in Odede and Enakerakpo (2014) defined ICT as short term for computers, software, networks, satellite links and related systems that allow people to access, analyze, create, exchange and use data, information and knowledge.

ICT is essential to mankind as it is necessary for improving businesses, economy, social life and meeting the information needs of modern society as well as the progress of the educational sector of any nation (Aduwa-Ogiegbaen \& Iyamu, 2005). Balasubramanian et al. (2009) stated that the use of ICT in education improves 
the quantity of education as well as its quality. This equally agrees with the view of Yushau and Nannim (2018) that ICT facilitates and enhances teaching and learning; as such, time and space are not obstacles to education any longer. ICT also creates room for inventive, informed and logical thinking, greateroutput, effectiveness, and informative results (Adeosun, 2010). This is not far from the view of Jung (2005) that ICT enhances both the method of learning and behavioral objectives as well as predicting the outcomes of teaching and learning in higher institutions of learning. Maybe, this is why the knowledge of ICT is very important for undergraduate students as they are part of the major focus of higher education. Youssef and Dahmani (2008) opined that using ICT enhances personalized and flexible learning by shifting learning process from the teacher to the students which thus, facilitate and adjust the classroom, educational institutions, communities and systems. It also facilitates the knowledge acquisition of learners, improves learners`skills, increases social mobility, empowers citizens to participate in global economy, and as a result, play a major role in improving the education structure (UNESCO, 2014).It was recommended by (Bakare \& Olaniyi, 2017) that, higher institutions in Nigeria should try to holistically encourage the use of innovative and modern technology in order to enhance teaching and learning that will enable the students equip themselves for an ideal world and a challenging environment. Particularly, technology integration in higher institutions in Nigeria must be adopted to support curricular goals of the institutions for higher quality education. This of course to the researchers is essential for proper use of ICT since it willfacilitate the acquisition of necessary skills needed by students in higher institutions in Nigeria for survival in this modern age and sophisticated economy.

The skills to use computer according to Akintunde (2004) is not the only ICT skill required to make valuable use of information stored in the internet. In order to make adequate use of these online resources, literacy in ICT or information is needed. Nikitakis (2007) referred to ICT skill as the ability to totally comprehend and acquire a whole lot ofcapacities, which include recognizing, spotting, evaluating information as well as making effective use of it. This may imply that alongside these fundamental skills, the abilities to inquire, communicate and collect information are essential. Using computers effectively is now a crucial part of every student's education. Haywood (2003) mentioned some core ICT skills which include knowledge of: spreadsheet, word processors, database and presentation. These ICT skills are essential in our present world in order to enable one have access and utilize information. These ICT skills are required in these contemporary times to enable students function effectively. UNESCO (2017) reiterated that ICT leads to general access to education, equity in education, transfer of quality learning and teaching, teachers' professional growth and efficient educative management, governance and administration. This thus implies that undergraduate students can improve their learning through proper and quality usage of ICT. As a result, universities, government and employers are expected to pay attention to undergraduates' ICT skills, because these are the people to restructure tomorrow.

In a study carried out by Siddiquah and Salim (2017), they noted that majority of the students have access to computers and internet facilities both at home and in the universities, as such, they possess some skills such as knowledge of Microsoft word, Microsoft PowerPoint, searching and browsing on the internet, social networking, e-mail, uploading file, and video games. Conversely, amidst these various skills possessed by the students, it is obvious that they lack other skills such as proper usage of e-library, discussion forums and blogging. Olurinola (2006) stated that PowerPoint should be used in teaching and learning as it facilitates learning among student. In a study by (Odede \& Enakerakpo, 2014), the researchers stated that undergraduate students possess adequate ICT skills and can efficiently make use of the internet.

Odede and Enakerakpo (2014) further added however that these skills were acquired by the students themselves through handbooks and manuals, friends and courses in their variousinstitutions. Consequently, (Siddiquah \& Salim, 2017) noted that the students engage themselves in doing other computer related activities instead of focusing on their academics. This is because, most of the students believed that using ICT ease their learning. Perhaps this is because everything is now at their fingertips courtesy of ICT.

Studies have however revealed that students face series of challenges in acquiring and utilizing these skills. (Anyim, 2018) stated that some of the challenges of acquiring ICT skills include;lack of funding, failure of the curriculum to include ICT, poor attitudes toward acquiring ICT skills, unavailability of training opportunities, poor ICTfacilities, high cost of ICT literacy training and lack of interest in digital information. Adeosun (2010) conducted a study describing the situation of ICT which was very particular about the state of things in Nigeria, as a great challenge to effective learning, the researchermentioned poor infrastructure as one of the major issue affecting the full implementation of ICT; very good internet access, proper and adequate hardware among other infrastructures are necessary for basic and advanced level of ICT enabled instructions. It is clear that in terms of computer access and usage, developed, developing and underdeveloped countries are not comparable; the difference is amazing as there are fewer computers and the usage in underdeveloped countries compared to develop and developing countries. The 
term Learner Computer Ratio (LCR) talks about number of learners to a computer for instructional objective in an educational system. It is almost a difficult practice to see underdeveloped countries build and facilitate the use of computer facilities compared to developing and developed countries where it is almost a common practice building and distributing computer and its facilities to educational institutions (UNESCO, 2014). Electricity supply according to (Aduwa-Ogiegbaen \& Iyamu, 2005) is also an infrastructure which supports ICT. This is very essential since no computer can actually function without power supply; however, this is a big challenge in the country as Nigeria is faced with the issue of epileptic power supply.Consequently, a good communication means is required for efficient delivery of information. Communication technology according to UNESCO, (2014) "may includenarrowband or broadbandfixed telephone line or a cable connection that connects terminal equipment to the telephone, or other telecommunication network". These challenges mentioned above are of course similar to the challenges noticed by Siddiquah and Salim $(2017$; 4993) they include; low processor speed of computers, weak or signal problem in using the Internet, virus threat, poor working conditions of computers, load shedding, and lack of access to internet are the problems faced by the majority of the students. Thus, they suggested that universities should make it a point of duty by investing more resources in order to improve infrastructures and as well proffer solution to ICT related issues so as to enable students' effective leaning. Thus, the reasons for the present study as it sought to find information on these emerging issues.

Manda and Mulkangara (2007) as cited in Alakpodia (2014) reported that gender is associated with the use of electronic information resources; the researchers added that male students were more likely to use e-resources than female students. Ramayah and Osman (2005) in their study mentioned that themales had more computer usage skills than their female counterparts. Contrary to numerous opinions that males perform better than females in ICT related facilities; Basri, Alandejani, \& Almadani (2018), carried out a study which revealed that in adopting the use of ICT the academic performance of girl students stand the chance of being improved more than boys.According to the study conducted by Kaminski, Switzer and Gloeckner, (2009), it was found that significance difference does not exist between undergraduate students in terms of the ICT skills of new students and old students. This of course agrees with (Strøms $\varnothing$, Grottum \& Lycke, 2004) that in term of ICT usages, the skills of students do not increase over time. This would imply that the skills of higher level students are not expected to differ from that of newer or lower level students in terms of ICT usage. Contradictory findings like these necessitated this study.

The place of ICT has become very essential in the affairs of mankind. The usage of ICT in every sector of life is very necessary as it facilitates growth; advances knowledge, increases productivity and human resources. ICT is relevant for improving infrastructures, economy and the education sector of any developing or underdeveloped nation. This of course has made ICT a pivotal for any undergraduate student that is expected to perform excellently. However, it is important to understand that to be able to effectively maximize the benefits of ICT towards learning; there are essential skills that students must possess to effectively do this. Quality learning can never be achieved through ICT if these skills are not acquired by students. Despite, the relevance of ICT to students learning, the education sector and the general good of any developing nation, it appears less or no attention is being paid to ICT in higher institutions of learning in the country which obviously is expected to produce students or individuals who would better compete with their counterparts in developed countries and as well drive the economy of their own nation. Several studies have however been carried out to bring these menace under control, yet the challenges persist. There is a need therefore to embark on this study as it sought to assess the various ICT skills relevant for effective learning possessed by undergraduate students.

\subsection{Purpose of the Study}

The purpose of this research work is to assess ICT skills relevant for effective learning possessed by undergraduate students in University of Nigeria, Nsukka.

\subsection{Research Questions}

1. What are the ICT skills possessed by undergraduate students for effective learning?

2. Do the ICT skills possessed by undergraduate students differ based on gender?

3. Do the ICT skills possessed by undergraduate students differ by educational level?

4. What are the challenges faced by students in utilizing the various ICT skills relevant for effective learning in the University? 


\section{Method}

\subsection{Research Design}

This study employed descriptive survey design. The study was conducted at the University of Nigeria Nsukka, South Eastern Nigeria. University of Nigeria Nsukka was chosen for this study because of her expertise and her rank as one of the best universities in Nigeria according to National University Commission (NUC) as published by World Scholastic Forum, 2020.

\subsection{Research Participants}

This study targeted undergraduate students; because majority of the postgraduate students have already acquired the necessary ICT skills for learning as part of the requirement for their admission into the university. Allundergraduate students (100 to 500 levels) made up the population for this study which comprise of 28,843 students (University Nigeria Nsukka Statistics Unit, 2020). Three hundred and twenty(320) students were sampled for the study as recommended by (Cozby, 2009). Convenience sampling technique was used to select the sample for the study.

\subsection{Measurement Approaches}

The instrument "Relevant ICT Skills for Effective Learning among Undergraduate Students Questionnaire" (RISELUSQ) was used for data collection. The instrument comprised five clusters based on the variables under consideration by the researchers. The clusters were arranged on a 4-point scale of Strongly Agreed, Agreed, Disagree and Strongly Disagree.

\subsection{Validity of the Instrument}

The instrument was validated by three experts, one from ICT unit of the university and two from Educational Measurement and Evaluation unit. Thirty eight (38) items were constructed before the validation, during the validation, some items were found to be irrelevant while others werefound to be double-barreled; moderations were made and after the validation, a total of 30 items were gotten.

\subsection{Reliability of the Instrument}

The instrument was trial test on undergraduate students with similar attributes from a nearby university. Cronbach-Alpha method was employed to estimate the internal consistency of the instrument since it is most suitable for polytomously scored items. A reliability index of 0.84 was obtained which shows that the instrument was reliable.

\subsection{Administration of the Instrument}

The instrument was administered on a face to face base so as to ensure maximum return. This was done by the researchers.

\subsection{Data Analysis}

The data gathered from the participants was evaluated with the statistics package program SPSS 23.0. The data were analyzed using Mean and Standard Deviation, t-test and ANOVA $(\mathrm{p}<0.05)$. 


\section{Results}

Table 1. Mean and Standard Deviation on ICT skills possessed by undergraduate students.

\begin{tabular}{|c|c|c|c|c|c|}
\hline & Item Statements & $N$ & Mean & $S D$ & Decision \\
\hline \multicolumn{6}{|c|}{ Knowledge of Word Processing/Excel } \\
\hline 1. & I have appropriate skills in using Ms-Word & 321 & 3.38 & .69 & A \\
\hline 2. & I have adequate skills to type my assignments using MS-Word & 321 & 3.45 & .68 & A \\
\hline 3. & $\begin{array}{l}\text { I have the skills to present and organize my assignments using } \\
\text { MS-Word }\end{array}$ & 321 & 3.40 & .62 & A \\
\hline 4. & $\begin{array}{l}\text { I have the appropriate skills to correct my errors, spellings and } \\
\text { grammatical structures in Ms-Word }\end{array}$ & 321 & 3.47 & .61 & A \\
\hline 5. & I have adequate skills to input information into Excel accurately & 321 & 2.95 & .76 & A \\
\hline 6. & I have the skills to perform some basic operations using Excel & 321 & 2.92 & .78 & A \\
\hline 7. & I have the skills to carryout calculations using Excel & 321 & 2.65 & .92 & A \\
\hline 8. & I possess adequate skills to analyze data set using Excel & 321 & 2.61 & .91 & A \\
\hline & Cluster Mean & & 3.11 & .75 & Agree \\
\hline \multicolumn{6}{|c|}{ Knowledge of PowerPoint } \\
\hline 9. & I have the required skills to use the PowerPoint & 321 & 3.01 & .84 & A \\
\hline 10. & $\begin{array}{c}\text { I possess the skills to make my presentations easier using } \\
\text { MS-PowerPoint }\end{array}$ & 321 & 3.23 & .76 & A \\
\hline 11. & $\begin{array}{c}\text { When my lecturers use PowerPoint, it makes the lecture so } \\
\text { interesting }\end{array}$ & 321 & 3.31 & .74 & A \\
\hline 12. & PowerPoint simplifies learning as it concretizes abstract concepts & 321 & 3.26 & .68 & A \\
\hline 13. & $\begin{array}{l}\text { Using the PowerPoint increases my skills to summaries as I learn } \\
\text { to present only key points }\end{array}$ & 321 & 3.17 & .79 & A \\
\hline & Cluster Mean & & 3.20 & .76 & Agree \\
\hline \multicolumn{6}{|c|}{ Knowledge of Search Engine } \\
\hline 14. & I know a lot of search engine (e.g Google, Ask.com, Bing etc.) & 321 & 3.56 & .61 & A \\
\hline 15. & $\begin{array}{l}\text { I possess adequate skills on several search engines in gathering } \\
\text { information for learning on the internet }\end{array}$ & 321 & 3.49 & .68 & A \\
\hline 16. & $\begin{array}{c}\text { Using Google and other search engines make my search on the } \\
\text { internet easy }\end{array}$ & 321 & 3.67 & .53 & A \\
\hline 17. & I have the skills to search for keyword when I need information & 321 & 3.55 & .58 & A \\
\hline 18 & I can bookmark pages for later use on many search engines & 321 & 3.44 & .67 & A \\
\hline 19. & $\begin{array}{l}\text { I possess the skills to manage several tabs at a time while } \\
\text { searching for information }\end{array}$ & 321 & 3.39 & .71 & A \\
\hline & Cluster Mean & & 3.52 & .63 & Agree \\
\hline \multicolumn{6}{|c|}{ Knowledge of the Internet } \\
\hline 20. & I possess adequate skills to find study materials online & 321 & 3.58 & .58 & A \\
\hline 21. & I have the skillsto make use of YouTube when studying at home & 321 & 3.22 & .79 & A \\
\hline 22. & $\begin{array}{l}\text { I have the skills to search for solutions to my assignments on the } \\
\text { internet }\end{array}$ & 321 & 3.49 & .61 & A \\
\hline 23. & I learn new things using social media platforms & 321 & 3.39 & .67 & A \\
\hline 24. & $\begin{array}{l}\text { I have adequate skills in usingonline classrooms to study ahead of } \\
\text { my lecturers }\end{array}$ & 321 & 2.74 & .82 & A \\
\hline 25. & $\begin{array}{l}\text { I can download PDF (Portable Document Format) files from the } \\
\text { internet for studying }\end{array}$ & 321 & 3.61 & .58 & A \\
\hline \multirow[t]{2}{*}{26.} & I know how to email my assignments to my lecturers & 321 & 3.37 & .80 & A \\
\hline & Cluster Mean & & 3.34 & .69 & Agree \\
\hline
\end{tabular}

Disagree $(\mathrm{D})=(1.5-2.49) ;$ Agree $(\mathrm{A})=(2.50-4.00)$ 
The result from the table 1 above incluster A (Knowledge of MS-Word/Excel) on ICT skill possessed by students for effective learning shows that all the items has mean above 2.50 and a ground mean of 3.11 with a standard deviation of 0.75 which is equally above the benchmark mean of 2.50 . It is therefore agreed that undergraduate students possess adequate knowledge of MS-Word/Excel which will enable them to learn effectively. Equally, in cluster B (Knowledge of PowerPoint) the mean responses for each the items are above 2.50 with a cluster grand mean of 3.20 and standard deviation of 0.76 which are all above the benchmark mean of 2.50 , hence it isagreed that undergraduate students in UNN possess the knowledge of PowerPoint. Again, in cluster C (Knowledge of Search Engine) the result shows that all the items means are above the threshold mean with a grand mean of 3.52 and a standard deviation of 0.63 , indicating an agreement that undergraduate students possess the knowledge of different search engines which can be used for learning effectively. Consequently, the result from cluster D (Knowledge of the Internet) indicates that undergraduate students possess the knowledge of internet as the mean of each item stands above the benchmark mean with a cluster grand mean of 3.34 and standard deviation of 0.69 which equally stands above the benchmark mean.Thus, it is agreed that undergraduate students of the university possess knowledge of basic ICT skills (knowledge of MS-word/Excel, PowerPoint, Search Engine and the Internet) which are relevant for them to study and learn effectively.

Table 2. Mean and Standard Deviation of ICT skills possessed by undergraduate students based on gender

\begin{tabular}{cccc}
\hline Gender of Students & $N$ & Mean & Std. Deviation \\
\hline Male & 186 & 3.31 & .34 \\
Female & 135 & 3.30 & .33
\end{tabular}

Table 2 above shows that the mean of the male undergraduate student is only slightly different from that of their female counterparts. However, both means of the male and female students show that the undergraduate students possess adequate ICT skills that enable them to learn effectively.

Table 3. Mean and Standard Deviation of ICT skills possessed by undergraduate students based on educational level

\begin{tabular}{cccc}
\hline Academic Level of students & $N$ & Mean & Std. Deviation \\
\hline 100 Level & 28 & 3.12 & .32 \\
200 Level & 55 & 3.29 & .30 \\
300 Level & 130 & 3.30 & .34 \\
400 Level & 60 & 3.31 & .33 \\
500 Level & 48 & 3.46 & .30
\end{tabular}

The result from table 3 above shows that the ICT skills of undergraduate students differ based on their educational level. The 500 level students have the highest skills, followed by 400 levels, 300 levels, 200 levels and 100 levels which have the least mean. Notwithstanding, the various means indicated that all the levels possess enough ICT skills that will help them to learn properly.

Table 4. Mean and Standard Deviation on the Challenges faced by students in utilizing ICT skills needed by undergraduate students for effective learning

\begin{tabular}{|c|c|c|c|c|}
\hline & Item Statement & $N$ & Mean & $\begin{array}{l}\text { Standard } \\
\text { Deviation }\end{array}$ \\
\hline 1. & The e-learning facilities in my school are limited & 321 & 3.19 & .77 \\
\hline 2. & $\begin{array}{l}\text { There is free-Wi-Fi all over the university environment for easy } \\
\text { surfing and learning on the internet }\end{array}$ & 321 & 3.01 & .90 \\
\hline 3. & $\begin{array}{l}\text { There are enough and functional projectors in almost all } \\
\text { classrooms in the university environment }\end{array}$ & 321 & 1.90 & .85 \\
\hline 4. & There are no e-learning classrooms/library in the university & 321 & 2.13 & .83 \\
\hline \multirow[t]{2}{*}{5.} & $\begin{array}{l}\text { There is no adequate power supply for effective usage of ICT } \\
\text { facility }\end{array}$ & 321 & 2.45 & .98 \\
\hline & Cluster Mean & & 2.54 & .87 \\
\hline
\end{tabular}


The result from table 4 above shows that there are limited e-learning facilities as agreed by the students in item 1 . Responses to item 2 show that there is free-Wi-Fi all over the university environment, as such, it is not a challenge. Also, responses to item 3 show that projectors are non-functional and lacking in the classrooms within the school environment. Item 4 shows that there are e-learning classrooms/libraries within the school, as such; it does not pose as a challenge. Finally, item 5 shows that the issue of power supply is not a challenge as responded to by the students.

Table 5. t-test analysis of the difference in the mean response of male and female undergraduate students on their ICT skills

\begin{tabular}{cccccccc}
\hline Group & $N$ & Mean & Std. Deviation & Df & $t$-cal & Sig. (2-tailed) & Decision \\
\hline Male & 186 & 3.31 & .34 & 319 & .46 & .75 & Not Sig. \\
Female & 135 & 3.30 & .33 & & & &
\end{tabular}

The table above show that the there is no significant difference in the mean response of male and female UNN undergraduate students in terms of the ICT skills they possess. This is because the table 5 shows that the probability associated with the t-value .46 for the difference in mean of ICT skills of male and female Undergraduate students of the University is .75. Thus, the $\mathrm{H}_{\mathrm{o}}$ is upheld.

Table 6. ANOVA Summary table for mean response on ICT skills based on educational level

\begin{tabular}{ccccccc}
\hline Variables & Sum of Squares & Df & Mean Square & $F$ & Sig. & Decision \\
\hline Between Groups & 2027.79 & 4 & 506.95 & 4.976 & .001 & Sig. \\
Within Groups & 32193.57 & 316 & 101.88 & & & \\
\hline
\end{tabular}

From the table 6 above, it is seen that the F-value (4.976) is significant at 0.001 . This level is less than the 0.05 level of significance which the $\mathrm{H}_{\mathrm{o}}$ hypothesis was tested at. Thus, the null hypothesis is rejected and there is therefore a significant difference in the ICT skills of undergraduate students in terms of their academic levels. This result was followed by a Post hoc test (Scheffe test) in table 7 to identify where the difference lie.

Table 7. Post Hoc multiple Comparison tables of ICT skills of undergraduate students based on educational level

\begin{tabular}{ccccc}
\hline $\begin{array}{c}\text { (I) Academic Level of } \\
\text { students }\end{array}$ & $\begin{array}{c}\text { (J) Academic Level of } \\
\text { students }\end{array}$ & $\begin{array}{c}\text { Mean } \\
\text { Difference(I-J) }\end{array}$ & Std. Error & Sig. \\
\hline 100 Level & 200 Level & -5.34156 & 2.34326 & .270 \\
& 300 Level & -5.50659 & 2.10290 & .147 \\
& 400 Level & -5.84762 & 2.31008 & .174 \\
& 500 Level & $-10.50595^{*}$ & 2.40020 & .001 \\
100 Level & 5.34156 & 2.34326 & .270 \\
& 300 Level & -.16503 & 1.62358 & 1.000 \\
& 400 Level & -.50606 & 1.88423 & .999 \\
300 Level & 500 Level & -5.16439 & 1.99369 & .155 \\
& 100 Level & 5.50659 & 2.10290 & .147 \\
& 200 Level & .16503 & 1.62358 & 1.000 \\
& 400 Level & -.34103 & 1.57533 & 1.000 \\
& 500 Level & -4.99936 & 1.70474 & .075 \\
& 100 Level & 5.84762 & 2.31008 & .174 \\
& 200 Level & .50606 & 1.88423 & .999 \\
& 300 Level & .34103 & 1.57533 & 1.000 \\
& 500 Level & -4.65833 & 1.95459 & .227 \\
& 100 Level & $10.50595^{*}$ & 2.40020 & .001 \\
& 200 Level & 5.16439 & 1.99369 & .155 \\
& 300 Level & 4.99936 & 1.70474 & .075 \\
& 400 Level & 4.65833 & 1.95459 & .227 \\
\hline
\end{tabular}

* The mean difference is significant at the 0.05 level 
The Post Hoc result in table 7 above shows the significance difference is only between the 100 level students and the 500 level students, whereas, no difference exist among other levels.

\section{Discussion}

The result of the analysis from table one showed that the students possess knowledge of Microsoft world/Excel, PowerPoint, Search Engines and the Internet. This shows that these skills are paramount for effective learning to take place in this ICT age. This agrees with the finding of the study carried out by Siddiquah and Salim (2017) that students possess basic knowledge on ICT skills such as knowledge of MS Word, MS Power Point, searching and browsing the internet and among others. This agreement is perhaps due to the reason that ICT has been found to be the driving force of this modern age and also enhances learning.

The result from table two revealed that there was no difference in the ICT skills possessed by both male and female students which would enhance their easy learning. This implies that both gender realized the crucial role ICT plays in facilitating learning. This is in disagreement with the findings of (Alakpodia, 2014; Ramayah \& Osman, 2005) who reported higher ICT skills in favor of male and also Manda and Mulkangara as cited in Basri, Aladejani and Almadani (2018) who reported that ICT adoption is more likely to favor the female than the male. Perhaps, this disparity is due to the fact that the studies were carried out in different location.

The result of the analysis from table three indicated that there exists a difference among the levels. An ANOVA result conducted further revealed that the difference was significant in the ICT skills possessed by the students. A Post Hoc (Scheffe) test was conducted to find out where the difference lies; it was found that the difference was only between 100 level and 500 level students. This could imply that as the students progress in their academics, they feel the need to continue to improve on their ICT skills so as to be able to meet up with the demands of each level in terms of ICT usage. This finding contradicts the findings of Kaminski, Switzer \& Gloeckner, (2009), who in their study reported that no difference exists between new and old undergraduate students in terms of their ICT skills and (Stromso, Grottum \& Lycke, 2004), who also stated that the usage of ICT does not increase with time among students. Perhaps, this difference is due to the reason that the studies were done in different environment and different skills were probably measured.

The result fromtable fourshows that students do not experience challenges in the area of Wi-Fi network, e-classrooms/libraries and in the area of power supply. However, students reported having challenges of limited e-classroom facilities and problem of non-functional/limited projectors in classrooms. This agrees with the results of (Ayim, 2005; Odede \& Enakerakpo, 2010) who reported infrastructures and facilities are a challenge of ICT among students and as such needs to be provided.

\section{Conclusions}

This study investigated the relevant ICT skills possessed by UNN undergraduate students that are relevant for effective learning. The result obtained and analysis of the data gotten led to the rejection of one null hypothesis and failure to reject one null hypothesis formulated in the study. The conclusion thus from this study is that UNN undergraduate students possess ICT skills that are useful for easy learning among the students. Based on gender, these skills do not differ significantly. Thus, gender has no significance influence on the ICT skills of male and female undergraduate students. However, in terms of the students` academic level, there is a significant difference in favor of the highest level. Hence, the ICT skills of undergraduate students are supposed to be increasing as they go higher in their academics. Consequently, it was shown that students face some challenges of infrastructures/facilities with respect to ICT in the university. It is therefore recommended that students be encouraged to continue to improve on their ICT skills as it will enable them strive well academically and that school authorities should ensure adequate and proper infrastructures/ICT facilities be put in place within the university environment. Also government should see to it that school development and ICT improvement funds be duly utilized by university bodies.

\section{Acknowledgements}

The researchers is very grateful to our colleague's and all the authors whose works were consulted during the process of this study

\section{References}

Adeosun, O. (2010). Quality basic education development in Nigeria: Imperative for use of ICT. Journal of International Cooperation in Education, 13(2), 193-211.

Aduwa-Ogiegbaen, S. E. \& Iyamu, E. O. (2005). Using information and communication technology in secondary schools in Nigeria: Problems and prospects. Educational Technology \& Society, 8(1), 104-112. 
Akintude, S. A. (2004). Libraries as tool for ICT development. A paper presented at the 2004 NLA National Conference and AGM, held at Akure 20-25 June, 2004. p10.

Alakpodia, O. N. (2014). Gender differences in computer use skill among students of school of health technology, Ufuoma, Delta State. International Journal of Digital Library Services,4(4), 1-11.

Anyim, W. O. (2018). Assessment of ICT literacy skills of digital library users and staff in Salem University Lokoja. Kogi. Library Philosophy and Practice (e-journal), 1-24

Bakare, A. A. \& Olaniyi, E. T. (2017). Use and Application of ICT in Teaching and Learning for Quality Higher Education in Nigeria. Greener Journal of Educational Research, 7(2), 015-020, http://doi.org/10.15580/GJER.2017.2.020617017

Basri, W. S., Alandejani, J. A. \& Almadani, F. M. (2018). ICT Adoption Impact on Students' Academic Performance: Evidence from Saudi Universities. Education Research International, 1-9. doi:https://doi.org/10.1155/2018/1240197

Balasubramanian, K., Clarke-Okah, W., Daniel, J., Ferreira, F., Kanwar, A., Kwan, A. \& West, P. (2009, July). ICTs for Higher Education. Background paper from the Commonwealth of Learning UNESCO World Conference on Higher Education. UNESCO World Conference on Higher Education Paris, 5 to 8 July 2009. Retrieved from http://unesdoc.unesco.org/images/0018/001832/183207e.pdf

Covenant, U. (2019). 160 Best Universities in Nigeria- Latest NUC Ranking. Retrieved on March, 10, 2020 from worldscholarshipforum.com

Cozby, P. B. (2009). Methods in Behavioral Research (10 ${ }^{\text {th }}$ ed.). Boston: McGraw-Hill.

Haywood, D. (2003). Confidence, experience and attitudes of undergraduate students towardsICT. Survey of European Universities Skills in ICT of Students and Staff (SEUSISS). URL: http://www.elearningeuropa.info/index.php?page=doc\&doc_id=4097\&doclng=1

Odede, I. \& Enakerakpo, E. (2014). ICT skills and internet usage among Library and Information Science students in Delta and Edo States, Nigeria. Internaltional Journal of Librry and Information Scinece, 6(5), 98-107. https://doi.org/10.5897/IJLIS2013.0360

Jung, I. (2005). ICT-Pedagogy integration in teacher training: Application cases worldwide. Educational Technology \& Society, 8(2), 94-101.

Kaminski, K., Switzer, J. \& Gloeckner, G. (2009). Workforce readiness: a study of university students fluency with information technology. Computers \& Education. http://dx.doi.org/10.1016/j.compedu.2009.01.017

Nikitakis, M. (2007). Proceedings of the $16^{\text {th }}$ Panhellenic Conference or Academic Libraries, Pireas, Greece. 1-3 October, 2007. 532-544.

Olurinola, O. D. (2016). Effect of presentation media on students learning outcomes in visual arts. Nigerian Journal of Educational Technology, 1(2), 69-77.

Ramayah, T. \& Osman, M. (2005). Complementing classroom teaching with an internet course website: Does gender and race matter. Proceedings of the 5th South East Asia Association for Institutional Research Conference. Westin Resort Nusa Dua, Bali, Indonesia, 14-16 September

Saddiquah, A. \& Salim, Z. (2017). The ICT facilities, skills, usage, and the problems faced by the students of higher education. EURASIA Journal of Mathematics Science and Technology Education, 13(8), 4987-4994. http://dx.doi.org/10.12973/eurasia.2017.00977a

Strøms $\varnothing$, H. I., Grottum, P. \& Lycke, K. H. (2004). Changes in student approaches to learning with the introduction of computer-supported problem-based learning. Medical Education. http://dx.doi.org/10.1046/j.1365-2923.2004.01786.x

UNESCO. (2002). Information and communication technology in education: a curriculum guide for schools and programs of teacher development. Division of Higher Education.Retrieved fromhttp://unesdoc.unesco.org/images/0012/001295/129538e.pdf.

UNESCO. (2006). Using ICT to Develop Literacy. Retrieved from UNESCO: www.unescobkk.org/education/ict.

UNESCO. (2014). Information and communication technology (ICT) in education in Asia: A comparative analysis of ICT integration and e-readiness in schools across Asia. Montreal: UNESCO Institute for Statistics. Retrieved April 18, 2020 from http://www.uis.unesco.org/Communication/Documents/ICT-asia-en.pdf 
UNESCO, (2017). ICT in Education. United Nation Educational Scientific and cultural Oranization: ParisUNN Statistic Unit (2020). University of Nigeria Statistics. University of Nigeria Nsukka (UNN).

Youssef, A. B. \& Dahmani, M. (2008). The impact of ICT on student performance in higher education: Direct effects, indirect effects and organizational change. RUSC.Universities and Knowledge Society Journal, 5(1), 13.

Yushau, B. \& Nannim, F. A. (2018). ICT facilities and their utilization for educational purposes in Nigeria Universities: A review of literature from 2004 to 2018. ATBU Journal of Science, Technology and Education, $6(1), 237-263$. 